\title{
THE DEVELOPMENT OF WAQF MANAGEMENT TRHOUGHT WAQF ACT IN INDONESIA (Note on Republic of Indonesia Act Number 41 of 2004 on Waqf)
}

\author{
Aden Rosadi', Deden Effendi², Busro 3 \\ 'Faculty of Sharia and Law, Universitas Islam Negeri (UIN) Sunan Gunung Djati Bandung \\ Jl. AH Nasution No. 105 Cibiru, Bandung, Jawa Barat, Indonesia \\ E-mail: adenrosadi@uinsgd.ac.id \\ ${ }^{2}$ Faculty of Sharia and Law, Universitas Islam Negeri (UIN) Sunan Gunung Djati Bandung \\ Jl. AH Nasution No. 105 Cibiru, Bandung, Jawa Barat, Indonesia \\ E-mail: dedeneffendi@uinsgd.ac.id \\ ${ }^{3}$ Faculty of Ushuluddin, Universitas Islam Negeri (UIN) Sunan Gunung Djati Bandung \\ Jl. AH Nasution No. 105 Cibiru, Bandung, Jawa Barat, Indonesia \\ E-mail: busro@uinsgd.ac.id
}

\begin{abstract}
The Development of Waqf Management Throught Waqf Act in Indonesia (Note on Republic of Indonesia Act Number 41 of 2004 on Waqf). Waqf is an Islamic endowment of property to be held in trust and used for a charitable or religious purpose. The development of waqf law in Indonesia, as one of religious institutions, is the realization of Muslim community needs to fulfill their religious life. The object of waqf that formerly was focused on immovable objects, with the presence of the Act has been broader to movable property, especially money waqf. This paper describes the urgency of civilization and the dynamics of waqf both from the side of law and its management in the context of people prosperity. By using library research that use qualitative data, this paper found the existence of waqf, normatively lies not only in the individual obligations, but also in social meaning in the context of collective obligations involving mawqûf bih (the property), wâqif (the person creating a waqf), nazir (the supervisor/manager of waqf), mauqûf 'alayh (waqf users), and the government through legislation. Basically, the Republic of Indonesia Act Number 41 of 2004 regarding Waqf is based on the philosophical, sociohistorical, and juridical foundation.
\end{abstract}

Keywords: waqf; wâqif; nazir; legislation.

\begin{abstract}
Abstrak: Pengembangan Manajemen Wakaf melalui Undang-Undang Wakaf di Indonesia (Telaah terhadap Undang-Undang RI Nomor 41 Tahun 2004 tentang Wakaf). Wakaf adalah sumbangan kekayaan dalam Islam yang pelaksanaannya diyakini berdasarkan keimanan dan digunakan untuk tujuan amal berbasis keagamaan. Pengembangan hukum wakaf di Indonesia, sebagai salah satu pranata keagamaan, merupakan realisasi kebutuhan masyarakat muslim untuk memenuhi kebutuhan kehidupan keberagamaan mereka. Objek wakaf yang sebelumnya terfokus pada benda-benda tak bergerak, dengan keberadaan undang-undang, telah meluas dan kini juga mencakup harta tak bergerak, terutama uang wakaf. Tulisan ini menggambarkan urgensi pembudayaan dan dinamika wakaf baik dari sisi hukum dan manajemennya dalam konteks perwujudan kesejahteraan masyarakat. Dengan menggunakan penelitian pustaka, yang menggunakan data kualitatif, tulisan ini menemukan bahwa wakaf, secara normatif, tidak hanya terletak pada kewajiban individu, tetapi juga dalam arti sosial dalam konteks kewajiban kolektif yang melibatkan mauqûf bih (hak milik yang diwakafkan), wâqif (orang yang mengeluarkan wakaf), nazir (supervisor/manager wakaf), mauqûf 'alayh (pengguna wakaf), dan pemerintah melalui undang-undang. Pada dasarnya, UU RI Nomor 41 tahun 2004 tentang Wakaf didasarkan pada landasan filosofis, sosio-historis, dan yuridis.
\end{abstract}

Kata kunci: waqf; wâqif; nazir; legislasi.

\section{Introduction}

The development of waqf (endowments) in Indonesia, as one of religious institutions, is the realization of Muslim community needs to fulfill their religious life. The Islamic Law (Sharia), as implied in the Quran and the Sunnah, urged the Muslim community to separate and set aside, or give away some of their belonging for the 
common interest. ${ }^{1}$ However, the Quran does not contain specific references on waqf. ${ }^{2}$ Its legal parameters were further developed by jurists (fuqâhâ') throughout history.

The basic idea lies in the belief that performing kindness is part of duty and form of devotion to God. The Muslim community develops the pillars and terms of waqf implementation. In this sense, its implementation is linked and bound by norms about what should and should not be done in waqf implementation. This waqf regulation is an inseparable part of Islamic Law (Sharia). It is closely linked to other areas of law and society, such as inheritance, will, grant, and marriage. Those areas are usually incorporated into the Civil Law. ${ }^{3}$

Generally, there are two basic forms of waqf. Those are family waqf (waqf ahlî/dhurrî) and common waqf (waqf khayrî). In the family waqf, profit that gained from waqf property ${ }^{4}$ is intended for the family wâqif benefit, as long as the waqf denoted theirs exist. The common waqf (waqf khayrî) forms eternal allocations on waqf purposes. Although waqf beneficiaries may come from family members, the philanthropic ethos

1 The utilization of waqf properties is various in the world. Generally, it is categorized into five categories, which are: foods, housing, health, education, and religious purposes. Further read: "Deden Effendi, Penegakan Hukum Wakaf di Indonesia", Ph.D Dissertation of UIN (Universitas Islam Negeri) Sunan Gunung Djati, Bandung, 2011, pp. 4-6.

${ }^{2}$ One of the most reffered histories of waqf is "Musadad, Yazîd Ibn Zurayj, and Ibn 'Awn relayed from Nâfi' and Ibn 'Umar, he said: "'Umar (may Allah be pleased with him [ABPWH]) had a piece of land in Khaybar which he loved the most, then came to the Prophet Muhammad (peace be upon him [PBUH]), to ask guidance for the land. Then the Prophet spoke "hold its staple and endow its result. "Umar (may Allah be pleased with him [ABPWH]). endowed the land, so it was not for sale, grant, and inherited. The property was donated to the poors, families, slaves, guest of Allah, and traveller; and for the property managers, they are allowed to consumed the harverst from the land but in sufficient manner" Abû Bakr Ahmad Ibn alHusayn Ibn 'Alî al-Baihaqî. (1352 H). al-Sunan al-Kubrâ, J. VI, AlHamîd: Mathba'ahDâ'irah al-Ma'ârif al-Uthmâniyya. p. 163.

${ }^{3}$ Due to the volunteer nature of waqf, it always separated from grant/donation (shadaqa) and zakât. Jaih Mubarok limits waqf based on: (1) legal acts, (2) waqf object; and (3) duration of property ownership. Even if waqf is related to zakât and shadaqa, there are some dimension of waqf that can be utilized as perimeters. Jaih Mubarok, Wakaf Produktif, Bandung, Simbiosa Rekatama Media, 2008.

4 Diharto, "Revitalization through Innovation WAQF Property Traditional Development" The International Journal of Business \& Management, Vol 4 Issue 9 September, 2016, pp. 240-243. of waqf institution leads to a larger portion of waqf for general welfare. In today's welfare-state context, waqf has great potential to support state's expenditures on public services.

Most people donate waqf in form of land..$^{5}$ This is related to the waqf conditions that it has to be secure and permanent as a shape of jâriyah charity (the never stop flowing virtue). Some movable property can also be used as waqf property. Waqf supervisor/manager (nazir) is required to perform their duties and functions in accordance with the prevailing provisions, as well as general provisions regarding attitudes and actions that have been established by Islamic teachings.

Basically, the implementation of waqf is almost the same throughout the Islamic world. However, there is diversity in theory, practice, and legal approach from one school of thought (mazhhab) to another ${ }^{6}$. State intervention in waqf law formulation has resulted to the diversity of waqf implementation among Islamic countries ${ }^{8}$. Therefore, the research results of waqf in the

${ }^{5}$ The information comes from waqf records in Istanbul, Jerussalem, Cairo, and other parts of Islamic world show that land waqf covered a large portion of agriculture land. For instance, land survery in Egypt in 1812 and 1813 exposed that land waqf covered 6.00.000 fedan ( 1 fedan $=0,95$ acre) from 2,5 million fedan Mustafe Muhammad Ramadhan, "Daur alAuqâf fî Da'm al-Azhar", in Proceeding of the Symposium of Awqaf Institutions in the Arab and Islamic World, (Institute of the Arab Research and Studies, Bagdad, 1983), p.93-112. The waqf impelementation in form of huge mosques in Aljazair in 183 was 534. Muhammad Abu al-Afhan, "al-Waqf 'alâ al-Masjid fî al-Maghribwa al-Andalūs", in Studies in Islamic Economics, Jeddah: King Abd al-Aziz University, International Center for Reserach in Islamic Economics, 1985, p. 315-342. One third of land in Turk were waqf properties, ServetArmagan, "Lamhah'an Hâlat al-AwqâffiTurki”, in Hasan'AbdAllâh al-Amîn, Idârawa TathmîrMumtalaka al-Awqâf, Jeddah: Islamic Research and Training Institute (IRTI) of the Islamic Development Bank, 1989, p.335-344. In Palestine, there were 233 recorded waqf consist of 890 properties, up to the $16^{\text {th }}$ century there were 92 individual waqf covered 108 properties (IRCICA, p.L)

${ }^{6}$ Bo Rothstein \& Rasmus Broms, "Governing religion: the long-term effects of sacred Financing" Journal of Institutional Economics/FirstView Article/September, 2013, pp 1-22. http:// dx.doi.org/10.1017/S1744137413000271

7 Mohd Afandi Bin Mat Rani, "Fatwa on Waqf: Specialized Analysis in Hand Over of Waqf Lands by State Authority", International Journal of Nusantara Islam, Vol. 3, No. 1, 2015, pp. 47-58, http://dx.doi.org/10.15575/ijni.v3i1.411

8 Savaş Alpay and Mohamed Aslam Haneef (eds.), Integration of Waqf and Islamic Microfinance for Poverty Reduction: Case Studies of Malaysia, Indonesia and Bangladesh, (IIUM-SESRIC, 2015), p. 4. 
Muslim world show historical distortions.

This is due to several events that occurred during the nineteenth century. ${ }^{9}$ Colonialization and nationalization have led to the weakening of this institution. Even the vast majority of people barely have basic knowledge of waqf. In many cases, colonial powers want a status quo on waqf $^{10}$. It was intended that the colonial policy can provide guarantee for social stability and legitimacy. At the same time, a large amount of unrecorded waqf property could be easily overrun by colonial rulers ${ }^{11}$.

After the colonial period, most Muslim countries tend to nationalize waqf-[s] property ${ }^{12}$, even abolishing them. Most Muslim countries, either directly or indirectly, administer waqf under special directorate or ministry, thus tend to end non-governmental waqf identity. The state's attempts to control waqf as one of means to extend power have always existed in Islamic history. At the same time, the efforts to make waqf as autonomous institutions are always challenged.

The lasting nature of the property in waqf ahlîl dhurrî has meaning and related to the transition from one generation to the next generation. A number of benefits increase to the point where the benefits of waqf are no longer significant to fulfill individual necessities. In this sense, the suggested argument is that sustainability is not always an absolute requirement in waqf implementation ${ }^{13}$.

${ }^{9}$ After the revolution in 1952 and the adoption of socialist system, the social and financial capitals were taken over by the ruling regime. On that time, the waqf institutions faded. The government abolished waqf ahlî, and at the same time controlled waqf kharî. Afterward, waqf culter in Egypt people gradually vanished, and the number of new waqf was not siqnificant. Muhammad AminTawfiq, "The Awqaf in Modern Egypt”, The Islamic Quarterly, vol. XLII, No. 4, 1998, pp. 257-265.

${ }^{10}$ Eric Lewis Beverley, "Property, Authority and Personal Law: Waqf in Colonial South Asia" South Asia Research,Vol. 31, 2011, pp. 155-82

"Siti Alawiah and Ismail, Yusof "Strategic planning and accountability of waqf management in Malaysia" $4^{\text {th }}$ International conference on Inclusive Islamic Financial Sector Development, 17th-18th Nov. 2015, International Islamic University Islamabad, (Unpublished).

${ }^{12}$ Adnan Trakic, "A Legal and Administrative Analysis of Inalienable Muslim Endowments (Awqâf) in Bosnia and Herzegovina" Islam and Civilisational Renewal, Vol. 3, No. 2, January 2012, pp. 337-354.

${ }^{13}$ Mesutldriz, "Waqf Property and Its Administration in
There is a common opinion, as suggested by orientalists, that the rigidity of waqf institutions is one of the reasons for economic weakening in the Islamic world ${ }^{14}$. However, this view was rejected by those who claimed that the waqf's flexibility in the Ottoman Turks period would not cause harm except the excessive regulation in the nineteenth century ${ }^{15}$.

Rather than restoring waqf institutions, most of post-colonial Muslim countries tended to eliminate them or nationalize waqf property ${ }^{16}$. The state's attempts to control waqf as a way to expand power take place throughout Islamic history, and are constantly facing challenges ${ }^{17}$. There is small number of empirical research on the management and nationalization of waqf property $^{18}$.

The indicator of waqf's economic potential actualization is the commonweal ${ }^{19}$ (al-mashlaha

the Ottoman Empire: a Case of Manastir with Special Reference to 18th Century Judicial Records. Hikmet: Ilmi Arastrima Dergisi, Journal of Scientific Research, 2005, pp. 19-26.

${ }^{14}$ Adeel Malik, "Was the Middle East's economic descent a legal or political failure? Debating the Islamic Law Matters Thesis" CSAE Working Paper, WPS/2012-08, 2012, Centre for the Study of African Economies Department of Economics. University of Oxford.

${ }^{15}$ Mehmet Babaca, "Economics of Philanthropic Institutions, Regulation, and Governance in Turkey", Journal of Economic and Social Research, Vol. 13, (2), 2011, pp. 61-89.

${ }^{16}$ Niccolo 'Pianciola and Paolo Sartori, "Waqf in Turkestan: the colonial legacy and the fate of an Islamic institution in early Soviet Central Asia, 1917-1924", Central Asian Survey,Vol. 26, (4), December 2007, pp. 475-498.

${ }^{17}$ Haitam Suleiman, "The Islamic Trust waqf: a Stagnant or Reviving Legal Institution?” Electronic Journal of Islamic and Middle Eastern Law (EJIMEL), Vol. 4, 2016, pp. 27-43.

18 Zunaidah Ab Hasan, Azhana Othman, Khalilah Ibrahim, Mohd Ab Malek Md Shah, Abd. Halim Mohd Noor, "Management of Waqf Assets in Malaysia" International Journal of Nusantara Islam, Vol. 3, No. 1, 2015, pp. 59-68, http://dx.doi.org/10.15575/ijni.v3i1.412; Noraini Mohamad, Zahanum Zulkifli" The Role of Higher Institutions in Creating Awareness on Challenges of MUIP in Communicating its Waqf Possession" International Journal of Nusantara Islam, Vol. 3, No. 1, 2015, pp. 69-76, http://dx.doi.org/10.15575/ijni.v3i1.413; Diana Farid Saleh "The Waqf of Money as a Community Economic Empowerment Efforts", International Journal of Nusantara Islam, Vol. 4, No. 2, 2016, pp. 27-36, http://dx.doi. org/10.15575/ijni.v4i2.1068; Yedi Purwanto, Hari Utomo, Rasyida Noor, "Nâzhir Al-Waqf in Imam Syafi'i's View and its Implementation in Indonesia", International Journal of Nusantara Islam, Vol. 4, No. 2, 2016, pp. 49-62, http://dx.doi. org/10.15575/ijni.v4i1.1202

19 Lukman Raimi, Ashok Patel and Ismail Adelopo, "Corporate social responsibility, Waqf system and Zakat system as faith-based model for poverty reduction", World Journal of Entrepreneurship, Management and Sustainable 
al-'âmma). The achievement of these goals is determined by the management efficiency and effectiveness. Consequently, the waqf management becomes the medium that bridges the potential and realization of the waqf implementation ${ }^{20}$. From another angle, waqf is a "legal act" obligation and prohibition of every factor that related to the waqf implementation, such as wâqif and nazir22.

Eventhough part of the waqf property has been abolished, nationalized, or mismanaged; there is an emerging proof of the awakening of attention, promotion, and rethinking of waqf as a social institution ${ }^{23}$. A number of community organizations, socio-political groups, and business units seek to utilize the waqf model in financial collection and management ${ }^{24}$.

There is enormous international support for the awakening of waqf ${ }^{25}$. It becomes part of the agenda Organization of Islamic Conference (QIC), the Islamic Development Bank (IDE), and The Islamic Educational, Scientific and Cultural Organization (ISESCO). In line with the world's political change, some ideologies emerge and

Development, Vol. 10 No. 3, 2014, pp. 228-242, http://dx.doi. org/10.1108/WJEMSD-09-2013-0052

${ }^{20}$ Lukman Raimi, "Waqf and Zakah as Social Safetynets for Poverty Reduction in Nigeria", WIEF-UiTM Occasional Papers,2nd Edition, 2015, pp-89-103

${ }^{21}$ Siraj Sait, "Unexplored dimension: Islamic land system in Afghanistan, Indonesia, Iraq, and Somalia". in Jon Unruh, Rhodri Williams, Land and Post-Conflict Peacebuilding, Routledge, 2013, p. 483.

${ }_{22}$ Ahmad Mikail, "Perspective of Siyasah Shar'iah in Application of Cash Waqf Transfer for Islamic Financial Industry: Indonesian Study Case", Proceeding of the 5th Islamic Economics System Conference (iECONS 2013), "Sustainable Development Through the Islamic Economics System", Organized By Faculty Economics And Muamalat, Universiti Sains Islam Malaysia, Berjaya Times Square Hotel, Kuala Lumpur, 4-5th September 2013.

${ }_{23}$ Muhammad Syukri Salleh, "Rethinking Wealth Management: An Islamic Preliminary View" International Journal of Business and Social Science, Vol. 3, No. 13, July 2012, pp. 232-236.

24 Salman Ahmed Shaikh, Abdul Ghafar Ismail, and Muhammad Hakimi Mohd Shafiai, "Application of waqf for social and development finance", ISRA International Journal of Islamic Finance, Vol. 9 No. 1, 2017, pp. 5-14, http://dx.doi. org/10.1108/IJIF-07-2017-002

${ }^{25}$ Abdulla Mohammed Al Awar, "Awakening the Awqaf: Islamic endowments represent a sleeping giant within the Islamic finance sector and the broader Islamic economy", 2015, http://gulfnews.com/business/sectors/banking/awakeningthe-awqaf-1.1595663, accessed 17 August 2017. change the perceptions of waqf recipients' and donors' groups.

For centuries, waqf has been became the subject of legal mechanisms study ${ }^{26}$. The findings show that waqf can be well managed when local actors have contribution to the management ${ }^{27}$. The future of this institution's resurgence will depend on the role of local actors, equipped with the ability to empower waqf. There are many examples of the adaptation of modern management and regulatory frameworks on waq $f^{28}$.

Innovative approaches to waqf property, including state's property, open wider access for people ${ }^{29}$. There is a special rule in the sharia regarding derelict property (mawât), which is not owned or utilized by any person or group of people, as in principle there should be no land being neglected. For example, the case of land in Medina, Saudi Arabia, which allows people to cultivate land that appeares neglected (mawât) ${ }^{30}$.

\section{Waqf Institution in Indonesia}

In Indonesia, the waqf institution has been embedded in Muslim societies' traditions. In fact, the age of this institution is as old as the age of Islamic history in this country. The

${ }^{26}$ Sabrina Joseph, "Waqf in Historical Perspective: Online fatâwâ and Contemporary Discourses by Muslim Scholars", Journal of Muslim Minority Affairs, Vol. 34, No. 4, 2014, pp. 425-437, http://dx.doi.org/10.1080/13602004.2014.9 65974

27 Rozalinda, "The Economic Empowerment of the Ummah on the Basis of Productive Waqf in West Sumatra, Indonesia", International Journal of Nusantara Islam, Vol .03, No .01, 2015, pp. 31-46, http://dx.doi.org/10.15575/ijni.v3i1.314

${ }^{28}$ SirajS ait and Hilary Lim, Land, Law and Islam: Property and Human Rights in the Muslim World, (Zed Books, London \& New York, 2006), p. 169

${ }^{29}$ Abdul Soma Thoarlim, Md. Asadur Rahman \& Anas Yanya, "Cash Waqf in Bangladesh and the Need for Innovative Approach towards Awqâf: Lessons from Selected Countries", International Journal of Academic Research in Business and Social Sciences, Vol. 7, No. 4, 2017, pp. 151-169. http://dx.doi. org/10.6007/IJARBSS/v7-i4/2795

${ }^{30}$ Edouard Al-Dahdah, Cristina Corduneanu-Huci, Gael Raballand, Ernest Sergenti, and Myriam Ababsa, Rules on Paper, Rules in Practice Enforcing Laws and Policies in the Middle East and North Africa, Directions in development. Washington, D.C.: World Bank Group, 2016 p. 99. http://documents.worldbank. org/curated/en/491731469074817610/Rules-on-paper-rules-inpractice-enforcing-laws-and-policies-in-the-Middle-East-andNorth-Africa, accessed 17 August 2017. 
historical proof of Islam arrival in Indonesia is determined through archaeological finds, such as graves or mosques ruins. Until now, the cemetery and the mosque became the object of waqf designation ${ }^{31}$.

The development of waqf institutions has changed. It crossed through the era of the sultanate, the colonial, the independence, and the reformation. At the sultanate time, it was governed by local customs ${ }^{32}$. In the colonial period, there were various interpretations on waqf regulations ${ }^{33}$. In the independence era, it governed by various regulations ${ }^{34}$. However, the vertical and horizontal relationships between regulations are not questioned. At the reformation era, when demands of regional and religious identities grew stronger, the formation of Waqf regulation was done by the Government (Act Number 41 of 2004). Based on philosophical35, socio-historical ${ }^{36}$, and juridical foundation ${ }^{37}$, waqf has become one of living laws in Muslim society in Indonesia.

For Muslim communities in Indonesia, waqf is align with the ideals of law, engrained in social life, and legally confirmed. Although it has fulfilled the living law criteria, it does not necessarily mean it becomes an "enforced law". The enforcement of the provisions contained in the "Waqf Act",

${ }^{31}$ Amelia Fauzia, Faith and the State: A History of Islamic Philanthropy in Indonesia,( Brill, 2013), p. 62.

32 Widyawati, "The Politics of Islamic Philanthropy in the post-Soeharto Indonesia: A Study of thezo04 Waqf Act" Advances in Natural and Applied Sciences, Vol. 6, No. 8, 2012, pp. 1438-1444.

${ }_{33}$ Uswatun Hasanah, "The Role of Indonesian Waqf Board in Promoting and Developing Waqf in Indonesia", Indonesian Management \& Accounting Research, Vol. 13, No.2, July 2014, pp.1-27.

34 Sudirman, "Regulasi Wakaf di Indonesia Pasca Kemerdekaan Ditinjau dari Statute Approach" de Jure, Jurnal Syariah dan Hukum, Vol. 6 No. 2, December 2014, pp. 190-203

35 Yulia Qamariyanti, "The Contextual of Waqf in Philosophy of Islamic Law Based on the Qur'an and Hadith" LamLaj, Vol. 1 Issue 1, March 2016,, pp. 15-26. See Iggi H. Achsien and Dien L. Purnamasari, "Islamic Crowd-funding as The Next Financial Innovation in Islamic Finance: Potential and Anticipated Regulation in Indonesia", EJIF - European Journal of Islamic Finance, No 5, June, 2016, pp. 1-10.

${ }^{36}$ Anouk Vandendael, Bas Hagoort, Jelle van Balen, \& Joppe Ter Meer, Stimulating Civil Society from the Perspective of an INGO: an Explorative Study of Indonesia, (Rotterdam School of Management: Erasmus University, 2013), pp. 3-39.

${ }^{37}$ Ahmad Atabik, "Strategi Pendayagunaan dan Pengelolaan Wakaf Tunai di Indonesia”, ZISWAF, Vol. 1, No. 2, December, 2014, pp. 315-335. will only be possible if the law is systematic, either vertically or horizontally, in Indonesian legal system, enforced by a clean and lawful official, and supported by a high legal awareness of those legal proponent. Without those conditions, the act will never be upright, but instead leads to sleeping ordonantie or even a dode regel (death law or death regulation).

By using library research that use qualitative data, this study will evaluate of the waqf management and its coherences with laws and regulations. This study is not intended to test a particular hypothesis or theory. However, it focuses more on searching new discoveries about phenomena, as they relate directly to the social realities. This research uses descriptive method with qualitative approach, also known as naturalistic. This is because in general the collected data is qualitative. Sources of obtained data, among others, are books that discuss about waqf. The normative aspect is based on Republic of Indonesia Act Number 41 of 2004 regarding waqf.

Data analysis was performed through three steps activities, which are classification, theorization, and interpretation. These steps are normative descriptive. This is related to the analized data's characteristics, which is qualitative. Finally, it will arrive at the conclusion part, which is the stage of inference as well as the answer to the question that was generated based on the analysis and interpretation of the collected sources.

\section{Waqf Regulation in Indonesia}

Waqf regulation in Indonesia exists since the enactment of Act Number 5 of 1960 regarding the Basic Regulation of Agrarian Principles or also called as the Act of Agrarian Principles, promulgated in the State Gazette Number 104 of 1960. Article 49 of the Act states: (1) the right to the property of religious and social bodies to the extent that they are used for religious and social activities are recognized and protected. These bodies are also guaranteed to obtain sufficient land for their buildings and businesses in the religious and social field, (2) for the worship and other sacred purposes, the property under 
direct state possession may be given with title the right of use, (3) the waqf of ownership-rights is protected and regulated under Government Regulation.

In order to carry out Article 49 paragraph 3 of the Act of Agrarian Principles, the Government Regulation Number 28 of 1977 regarding the Rights of Ownership waqf was passed. After the birth of GR Number 28 of 1977 which regulates land waqf, the Presidential Instruction Number 1 of 1991 regarding the Compilation of Islamic Law (KHI) was enacted. It regulates waqf in more comprehensive manner, along with marriage and inheritance regulation. In this compilation, the waqf object is not limited to the land with the rights of ownership title. 13 years from the $\mathrm{KHI}$, the government legislated Act Number 41 of 2004 regarding waqf. Besides bringing some new ideas, this Act specifically discusses more detail about waqf and its management.

The Act Number 41 of 2004 becomes a strategic breakthrough for the future development of waqf in Indonesia. So called because this Act covers important points, ${ }^{38}$ including: the law emphasizes the necessity of waqf empowerment as a religious institution that has economic potential and benefits for the worship importances and promotes public welfare; the law regulates broader implementation of waqf, which are: the permissibility to waqf movable-objects, whether in form of money, shares, securities, intellectual property, precious metals, and others. The arrangement of cash waqf turns ourt to be an enormous opportunity for the future development of waqf. ${ }^{39}$ Since money is flexible, the empowerment plan will be more attainable; nazir (waqf manager or waqf supervisor) as the backbone of waqf management is divided into individual, organization, and legal entity. This arrangement is intended for more professional waqf management, and to avoid the occurrence of violation on the objects of waqf; the role of selected sharia financial institutions,

${ }^{38}$ Thobib Al-Asyhar, "Substansi Undang-Undang Nomor 41 Tahun 2004 tentang Wakaf", Paper in Workshop of Pemberdayaan Wakaf di Jawa Barat", 2006. p. 3.

39 Ibrahim, Amir \&Masron., "Cash Waqf: An Innovative Instrument for Economic Development", International Review of Social Sciences and Humanities, Vol. 6, No. 1, 2013, pp. 1-7 in Islamic financial system, should be based on Islam fully, not just the name and label only. It must reflect the philosophy, values, ethics and objectives of Islamic Shariah, ${ }^{40}$ appointed by the Minister of Religious Affairs, as a place to entrust waqf money and entitled to issue a Certificate of Endowments/Waqf (Sertifikat Wakaf Uang); to optimize Waqf management and development, an independent Indonesian Wakaf Board (Badan Wakaf Indonesia) is established and may inaugurate a representative at province and district level if deemed necessary; in the management and development of waqf property, nazir may cooperate with third parties and pledge to sharia insurance; disputes settlement over waqf property, shall use mediation, arbitration, or legal trial/litigation.

The existence of general criminal provisions against waqf property and management violation as follows:

a. For those who deliberately pledge, grant, sell, inherit, and other forms of rights transference without permission will be convicted with imprisonment for a maximum of 5 (five) years and /or a fine of not more than Rp 500.000.000,00 (five hundred million rupiah).

b. For those who deliberately change the designation of waqf property without permission will be convicted with imprisonment for a maximum of 4 (four) years and /or a fine of a maximum of Rp. 400,000,000.00 (four hundred million rupiah).

c. For those who deliberately use or take the facilities resulted from waqf revenue beyond the prescribed amount, shall be convicted with imprisonment for a maximum of 3 (three) years and/or a fine of not more than Rp 300,000,000.00 (three hundred million rupiah). ${ }^{41}$

${ }^{40}$ Mohamad Zaid Mohd Zin, Ahamad Asmadi Sakat, Nurul Khairiah Khalid Nurfahiratul Azlina Ahmad, Mohd Roslan Mohd Nor, Azri Bhari, Saurdi Ishak and Mohd Arip Kasmo, "Products of Islamic Finance: A Shariah Compliance Advancement” Australian Journal of Basic and Applied Sciences, Vol. 5, (12), 2011, pp. 479-484.

${ }^{41}$ Mohamad Zaid Mohd Zin, Ahamad Asmadi Sakat, Nurul Khairiah Khalid Nurfahiratul Azlina Ahmad, Mohd Roslan Mohd Nor, Azri Bhari, Saurdi Ishak and Mohd Arip Kasmo, "Products of Islamic ...p. 479-584. 
This law, as outlined in the Act explanation, is based on two reasons. First, the objective of the Unitary State of the Republic of Indonesia as mandated in the Preamble of the 1945 Constitution of the Republic of Indonesia is to promote the general welfare. ${ }^{42}$ To achieve these objectives, it is necessary to explore and develop the potentials that exist within religious institutions that have economic benefits.

One of the strategic steps to improve general welfare is to increase the role of waqf as a religious institution that not only aims to provide various religious and social facilities, but also has economic power potential to promote the general welfare. ${ }^{43}$ Thus, its utilization should be developed in accordance with sharia principles.

Secondly, the practice of waqf that occurs in society has not been fully run orderly and efficient. ${ }^{44}$ Many cases show how waqf property is not properly preserved, abandoned, or unlawfully handed to third parties. Such circumstances are not solely occure due to the negligence or inability of nazir in managing the waqf property but also because of people's ignorance or unawareness of waqf status, where it should be protected for the purpose of general welfare, in accordance with the purpose, function, and allotment of waqf.

Based on the above considerations and to meet legal demand in the framework of national law development, the "Act on Wakaf" was created. Basically, the previous waqf provisions, both from sharia and national regulations, are re-enacted in this Act. In addition, there are some new issues as follows: first, to create the order of law and waqf administration to protect waqf property, this Act affirms that waqf legal acts

${ }^{42}$ Sukasih, Kamaruzaman Yusoff and Mansoureh Ebrahimi" Humanism Values in the 1945 Constitution of Republic of Indonesia", The Social Sciences, Vol. 11,No. 5, 2016, pp. 540-546.

${ }^{43}$ Farhana Mohamad Suhaimi and Asmak Ab Rahman, "The role of share waqf in the socio-economic development of the Muslim community The Malaysian experience", Humanomics, Vol. 30, No. 3, 2014, pp. 227-254, http://dx.doi. org/10.1108/H-12-2012-0025

${ }^{44}$ Hasyeilla Abd Mutalib \& Selamah Maamor, "Utilization of Waqf Property: Analyzing an Institutional Mutawalli Challenges in Management Practices", International Journal of Economics and Financial Issues, Vol. 6 No. S7, 2016, pp. 36-41. must be recorded and written in the deed of waqf pledge, registered, and announced which its implementation is performed in accordance with the procedures regulated in the waqf regulations. This law does not separate between the waqf-ahlî (dhurrî) and Waqf khayrî. Waqf-ahlî (dhurrî) is applied when the waqf management and utilization is limited to the wâqif's heirs, while waqf-khayrî is intended for public benefit, in accordance to the purpose and function of waqf; second, In the past, people understood that waqf is limited on immovable objects such as land and building. Based on the Act, wâqif can also endow their movable wealth, whether tangible or intangible, such as money, precious metals, securities, vehicles, intellectual property rights, rights to lease, and other movable objects; third, in the case the movable objects is money, wâqif may endows through Sharia Financial Institutions. Sharia Financial Institution is an Indonesian legal entity established based on Islamic finance laws and regulations, for example a sharia bank. The waqf of movable object in form of money through a Sharia Financial Institution is intended to facilitate wâqif to donate their money; forth, waqf property is not solely proposed for religious and social facilities, but also directed to promote general welfare by reaching the economic potential and benefits of waqf property. $45 \mathrm{It}$ allows the waqf properties management to enter of economic activities in a broad sense, as long the activities use sharia economic and management principles as foundation.

To secure the waqf property from third parties interference that harming waqf purposes, it is necessary to improve the nazir professional capacity. The Act also regulates the establishment of Indonesian Wakaf Board (BWI [BadanWakaf Indonesia]) that may assemble local representation as needed. The Board is an independent institution that performs duties in waqf matters, gives guidance to nazir, conducts the management and development of national and international level waqf properties, gives

${ }^{45}$ Mahata, Jaaffara \& Rasool, "Potential of Micro-Waqf as an Inclusive Strategy for Development of a Nation", International Accounting and Business Conference 2015, IABC 2015, Procedia Economics and Finance, Vol.31, 2015,pp. $294-302$. 
approval on any proposed alteration of waqf property status and designation, and provides advice and consideration to the government in formulating policies that related to waqf. ${ }^{46}$

The provisions in point one above, although claimed as new, are basically similar to Article 5 of the Government Regulation of the Republic of Indonesia Number 28 of 1977 regarding the Rights of Ownership waqf that stipulates:

(1) The party who endows (gives waqf of) his/ her land must pledge his/her will clearly and firmly to the nazir before the Official of Waqf Pledge Deed as referred to Article 9 clause (2) whom then record it on Waqf Pledge Deed, witnessed by at least 2 (two) witnesses.

(2) Under certain circumstances, any deviation upon the provisions referred to in article (1) may be applied under approval of the Minister of Religious Affairs.

The waqf pledge is stipulated in articles $17-21$ as follows:

(1) Wakaf pledge was performed by wâqif to nazir in front of the Official of Waqf Pledge Deed (PPAIW [Pejabat Pembuat Akta Ikrar Wakaf]), witnessed by 2 (two) witnesses.

(2) The endowment (waqf) pledge as referred to in paragraph (1) shall be declared verbally and /or written and stipulated in the deed of waqf pledge by Official of Waqf Pledge Deed (PPAIW).

\section{Article 18}

In the case of wâqif are unable to express waqf pledge orally or unable to present in the waqf pledge recital for reasons justified by law, wâqif may designate his proxy by a power of attorney, and reinforced by two witnesses.

\section{Article 19}

To be able to perform waqf pledge, wâqif or their attorney submits a letter and/or ownership proof of waqf property to PPAIW.

\section{Article 20}

Witnesses in the waqf pledge must meet the following requirements:

\footnotetext{
${ }^{46}$ Explanation of Act No. 41 of 2004
}
a. adult;
b. muslim;
c. sensible;
d. not hindered to perform legal action.

\section{Article 21}

(1) The waqf pledge is stated in the deed of waqf pledge.

(2) The deed of waqf pledge as referred in paragraph (1) shall at least contain:
a. Name and identity of wâqif;
b. Name and identity of nazir;
c. Data and information of waqf property;
d. Allotment of waqf property;
e. Waqf duration.

(3) Further provisions concerning the deed of waqf pledge as referred in paragraph (2) shall be regulated by Government Regulation.

\section{The Substance of Act Number 41 of 2004 a. The systematic of Act Number 41 of 2004}

The Act Number 41 of 2004 on Waqf is recorded in the Republic of Indonesia State Gazette Number 159 and Supplement to the State Gazette Number 4459 of 2004, came into force on 27 October 2004. The Systematic of the Act is as follows:

CHAPTER I: General Provisions (1 article: 1 )

CHAPTER II: Principles of Waqf

A. General (2 articles: 2-3)

B. Purposes and Functions of Waqf (2 articles: 4-5)

C. Elements of Waqf (1 article: 6 )

D. (2 articles: 7-9)

E. Nazir (6 articles: 9-14)

F. Waqf Property (2 articles: 15-16)

G. Pledge of Waqf (5 articles: 17- 21)

H. Allotment of Waqf Property (2 articles: 22-23)

I. Endowment (Waqf) through Testament (4 articles: 24-27)

J. Waqfon movable objects in form of money/ cash (4 articles: $28-31$ )

CHAPTER III: Registration and the Announcement of Waqf Property (8 articles: 32-39)

CHAPTER IV: Changes in the Status of Waqf 
Property (2 articles: 40-41)

CHAPTER V: Management and Development of Waqf Property (5 articles: 42-46)

CHAPTER VI: Indonesian Waqf Board
A. Position and Duties (4 articles: 47-50)
B. Organization (2 articles: $51-52$ )
C. Member (2 articles: $53-54$ )
D. Appointment and Dismissal 4 articles: 55-58)
E. Financing (1 article: 59 )
F. Implementation Conditions ( 1 article: 60 )
G. Accountability (1 article: 61 )

CHAPTER VII: Dispute Resolution (1 article: 62 )

CHAPTER VIII: Development and Supervision (4 articles: 63-66)

CHAPTER IX: Penal Provisions and Administrative Sanctions
A. Penal Provisions (1 article: 67 )
B. Administrative Sanctions (1 article: 68)
CHAPTER $X:$ Transference Provisions (2 articles: $69-70$ )
CHAPTER XI: Closing Provisions (1 article: 7 )

\section{b. The Concept of Waqf and Its Elements}

According to Act Number 41 of 2004, waqf is a wâqif legal act to separate and /or bestow some of their property to be utilized forever or for a certain period for the purposes of worship and /or general welfare based on sharia (article 1, paragraph 1).The elements of waqf in this Act are 5 (five), namely: (1) wâqif, (2) nazir, (3) waqff property, (4) pledge of waqf, (5) Allotment of waqf property, and (6) period of waqf (article 6).

Wâqif is the party who donates their property (article 1, paragraph 2). Wâqif may be individuals, organizations, or legal entities (art. 7). Individual wâqif must meet the following requirements:
a. Adult,
b. Sensible,
c. Not hindered to perform legal action, and
d. The rightful owner of waqf property (article 8, paragraph 1).

While wâqif organizations or legal entities may perform waqf if they meet the provisions of the organization or legal entity to denominate property owned by the organization or legal entity in accordance with their respective article of association (article 8, paragraphs 2 and 3).

Parties who receive waqf property from wâqif to be managed and developed in accordance with its designation are called nazir. Nazir may be an individual, an organization, or a legal entity (art. 9). Individual nazir must be an Indonesian citizen, Muslim, adult, trustworthy, able both physically and spiritually, and not hindered to perform legal action.

Nazir organization consist of managers who meet meets the requirements of the individual nazir above. The organization engages in social, educational, civic, and/or islamic activities (article 10, paragraph 2). Likewise, the legal body entity consists of legal body executives who meets the requirements of an individual nazir, and the legal entity shall be established in accordance with Indonesian laws and regulations, and engages in social, educational, civic and Islamic activities (article 10, paragraph 3). The task of nazir covers:

a. administering waqf property;

b. manage and develop the waqf property in accordance with the purpose, function, fund allocation;

c. supervise and protect the properties of waqf; and

d. reports the completion of duties to the Indonesian Wakaf Board (BWI) (article 11).

To perform the above duties, nazir shall be entitled to receive rewards from the net return on the management and development of waqf property $10 \%$ (ten percent) in maximum, and shall be entitled to obtain training and education from the Minister and the Indonesian Wakaf Board (articles 11 and 12). In the meantime, to obtain the above education, nazir must be registered in the Minister and the Indonesian Wakaf Board (BWI).

Waqf properties in this Act include immovable objects and movable objects. Immovable objects are:

a. rights upon land, based on the existing regulations, both registered and nonregistered land;

b. buildings or parts of buildings standing on 
the land as referred in letter (a);

c. plants and other objects related to the land;

d. ownership of a flats property in accordance with the existing laws and regulations; and

e. other immovable property in accordance with the provisions of sharia and existing laws and regulations.

Movable objects are property that can not be depleted from consumption, namely: money, precious metals, securities, vehicles, intellectual property rights, lease rights, and other movable objects in accordance with the provisions of sharia and existing legislation (Article 16, paragraphs1-3).

The next element of waqf is the vow of waqf. The Pledge is recited by wâqif to nazir in front of PPAIW witnessed by 2 (two) witnesses. The pledge may be verbally or in writing, and transcribed in the deed of waqf pledge, or if waqif is unable to attend, may designate its proxy by a power of attorney reinforced by 2 (two) witnesses. Waqf pledge can be performed if wâqif can submit a letter or ownership proof of waqf property to PPAIW (chapters 17-19).

To achieve the purpose and function of waqf, waqf property is designated for:

a. worshop facilities and activities;

b. education and health facilities and activities;

c. support to the poor, abandoned children, orphans, and scholarships;

d. development and improvement of the people's economy;

e. other general welfare improvement that are not contrary to sharia, laws and regulations (article 22).

Endowments of movable objects in the form of money can be performed by wâqif through sharia financial institutions appointed by the Minister. Waqf money is acted with a written statement of wills, and then issued in form of waqf money certificates, issued by Islamic financial institutions to wâqif and nazir as a proof of waqf property bestowal (articles 28-29). Islamic financial institutions on behalf of nazir register the waqf money to the Minister at least 7 (seven) working days since the issuance of Certificate of Waqf Money (article 30). Waqf property that has been bestowed are prohibited to be used as security, confiscation, donation, sale, inheritance, exchanged or transferred in other form of rights transference ${ }^{47}$.

\section{c. Management and Development of Waqf Property}

In principle, the management and development of waqf property must correspond to the purpose, function and designation ${ }^{48}$. In the process, nazir is prohibited to make changes the waqf property designation ${ }^{49}$ except has written permissions from the Indonesian Wakaf Board (BWI). Related to this, nazir may be dismissed or replaced if:

a. deceased, for the individual nazir;

b. dissolved or being dissolved, for the organization or legal entity nazir;

c. upon their own request;

d. does not fulfill their duties as nazir and /or violates waqf management and development regulations;

e. Sentenced to a criminal by a court that has had permanent legal force (article 45, paragraph 1).

The dismissal and replacement of nazir is executed by the Indonesian Wakaf Board (article 45, paragraph 2).

\section{d. Guidance and supervision}

Guidance and supervision upon the implementation of waqf is performed by the Minister by involving the Indonesian Wakaf Board (BWI) and by taking into account the suggestions and considerations of the Indonesian Council

47 Siti Mariam Malinumbay S. Salasal, The Concept of Land Ownership: Islamic Perspective, Buletin Geoinformasi, (Penerbitan Akademik Fakulti Kejuruteraan \& Sains Geoinformasi,), Jld. 2 No.2, ms. 285-304, December 1998

${ }^{48}$ Nor Asiah Mohamad, Sharifah Zubaidah Syed Abdul Kader \& Zuraidah Ali, "Waqf Lands and Challenges from the Legal Perspectives in Malaysia”, IIUM-Toyo Joint Symposium 2012, Sustainable Built Environment: lesson learned from Malaysia and Japan.

49 Hussein Elasrag, Towards a new role of the institution of waqf, Online at https://mpra.ub.unimuenchen.de/80513/ MPRA Paper No. 80513, posted 1 August 2017 05:31 UTC. 
of Ulama (MUI) (article 63 verses 1-3). In the framework of the aforementioned guidance, the Minister and BWI may cooperate with public organizations, experts, international bodies, and other deemed necessary parties, including the use of public accountants (articles 64 and 65 ).

\section{The Philosophical, Socio-historical, and Juridical Foundation}

The birth of Republic of Indonesia Act Number 41 of 2004 regarding waqf is one of qualitative progress of waqf management in Indonesia ${ }^{50}$. Its enactment is based on various foundations. As an act, at least it should be created on $^{51}$ philosophical ${ }^{52}$, sociological ${ }^{53}$, and juridical ${ }^{54}$ foundation.

Firstly, the philosophical foundation. This foundation is more focused on the ideals of law as set forth in the preamble. The ideals of law in question are law enforcement and justice as reflected in the constitution of the Republic of Indonesia55.

Secondly, the socio-historical foundation. This foundation is more focused on dynamics aspects and interaction process of Muslim life which inherent with the implementation of Islamic law in Indonesia. Nevertheless, sociologically the act is not fully reflecting the aspirations

50 Hidayatul Ihsan, Shahul Hameed $\mathrm{Hj}$. Mohamed Ibrahim, "WAQF accounting and management in Indonesian WAQF institutions: The cases of two WAQF foundations" Humanomics, Vol. 27, Issue: 4, 2011, pp. 252-269, https://doi. org/10.1108/08288661111181305

51 Muhammad Ishom, "The Effectiveness of Law No. 41 Year 2004 About Regulation of Productive Waqf" Jurnal Bimas Islam, Vol.7. No. IV, 2014, pp. 663-698.

${ }^{2}$ Mochammad Arif Budiman, "The Significance of Waqf for Economic Development" Equilibrium, Volume 2, No.1, June 2014, pp. 19-34.

53 Yuli Rofai, Umar Burhan, Multifiah Multifiah. The Role of Productive Waqf for Public Welfare (Study Case of Nadzir Foundation in University of Islam Malang). International Journal of Social and Local Economic Governance, Vol 2, No 2,2016, pp. 152-160.

54 Siti Muflichah, " Implementation and Protection of Legal Law on Cash Waqf Toward Tabung Wakaf Indonesia of Dompet Dhuafa Jakarta" Jurnal Dinamika Hukum, Vol. 17 No. 2, May 2017, pp. 119-124.

55 Muhammad Ishom, Nadirsyah Hosen, "Religion and Indonesian constitution: A recent debate" Journal of Southeast Asian Studies, Vol. 36, Issue 03, October 2005, pp. 419-440, http://dx.doi.org/10.1017/So022463405000238 of the entire Muslims society in Indonesia. ${ }^{56}$

Thirdly, the juridical foundation. This foundation has a solid normative approach, based on the Act Number 10 of 2004 regarding the Formation of Laws and Regulations. In real terms, the 1945 Constitution becomes the main normative-juridical reference in arranging legislation ${ }^{57}$.

\section{Discussion}

Sharia is a sacred law which originates from the will of Allah. ${ }^{8}$ In the legal study, sharia is a natural law which remains constant and does not change. ${ }^{59}$ However, in the case of waqf, shariah does not define waqf strictly and in detailed way. ${ }^{60}$ In this case, the legal provision of waqf is obtained through ushûl al-figh, ${ }^{61}$ with a deductive reasoning pattern analogy. Furthermore, the provision on waqf mechanism is based on human preference for public good, such as istihsân, ${ }^{62}$ mashlahah mursalah,, ${ }^{63}$ 'urf, ${ }^{64}$ and so forth. Legal resources are focused more on human thinking and behavior. In this sense, Muslims recognize the legal postivism.

The power of sharia as a qânûn depends on the authority holder. The validity of a law is naturally determined by the holder of political

56 Muhammad Ishom, Siraj Sait, "The Relevance of Islamic Land Law for Policy and Project Design" Conference on Challenges for Land Policy and Administration, Washington DC., the World Bank. 2008

57 Muhammad Ishom, Suryani and Yunallsra, "Wakaf Produktif (Cash Waqf) dalam Perspektif Hukum Islam danMaqâshid Al-Sharî‘ah" Walisongo: Jurnal Penelitian Sosial Keagamaan, Vol. 24 No. 1, May 2016, pp. 17-36.

${ }^{58}$ Hamid R. Kusha, "The Sacred Law of Islam: A Case Study of Women's Treatment in the Islamic Republic of Iran's Criminal Justice System", Routledge, 2017, p. 62.

59 Louay Fatoohi, Abrogation in the Qur'an and Islamic Law, (Routledge, 2012), p. 224.

${ }_{60}$ Majid Khadduri \& Herbert J. Liebesny, Origin and Development of Islamic Law, (The Lawbook Exchange, Ltd 2008), p. 82.

${ }_{61}$ Peri Bearman, The Ashgate Research Companion to Islamic Law, (Routledge, 2016), p. 52.

62 Saim Kayadibi, Istihsan: The Doctrine of Juristic Preference in Islamic Law, (The Other Press, 2010), p. 273.

${ }_{63}$ Nur Asiyah \& Abdul Ghofur, "Kontribusi Metode Mashlahah Mursalah Imam Malik terhadap Pengembangan Hukum Ekonomi Syari'ah Kontemporer", Al-Ahkam, 27 (1), 2017, pp. $59-82$.

${ }^{64}$ Cholil Nafis "Rethinking” Fiqih Wakaf. 2011, https://bwi. or.id/index.php/in/publikasi/artikel/751-rethinking-fiqih-wakaf. html, accessed June, 27, 2018. 
authority. Yet, the presence of fiqh (not qânûn) indicates that the norm validity is developed by holders of scientific authority ('ulamâ' or fuqâhâ'), and they commonly have an independent postiton or beyond the political structure. Colonialization and modernization require sharia and figh to adopt the modern legal system. Not all sharia norms can be simply adapted into the modern legal system. ${ }^{65}$ This matter is related to the sharia coverage in human life affairs. The more "neutral" sharia is (with no detailed and strict rules in sharia), the easier the process of adaptation of sharia into the modern legal system will become, as its regislation mechanism will depend on the creativity of scholars. ${ }^{66}$

The law of waqf is based more on the spirit of law, the spirit of Islamic teaching, and the maqâshid al-shari'ah than the text of sharia, so that waqf is more likely to be developed to respond the demands and needs of community. The law of waqf has a great chance to take place, so that in turn it functions to be a means to increase and empower waqf potential. ${ }^{67}$

The power and existence of waqf in Indonesia is not merely related to the ideals of law as part of the living law in society. Moreover, waqf has a relationship with the spirit of the implementation of the national legal system in the form of Law on Wakaf Number 41, 2014. In Indonesia, the waqf institution is inherently embedded in the tradition of Muslim society. It is no room for doubt that the age of the institution is as old as the age of Islamic history in Indonesia. The historical evidence of the arrival of Islam in Indonesia is based on archaeological findings, such as graves or ruins of mosques. The graves and mosques have been the object of waqf until the present time. ${ }^{68}$

The development of waqf institution met some changes as it passed the kingdom period,

\footnotetext{
${ }^{65}$ Ahmad Atif Ahmad, Islamic Law: Cases, Authorities and Worldview, (Bloomsbury Publishing, 2017), p. 132.

${ }^{66}$ Meir Hatina, Guardians of Faith in Modern Times: 'ulama' in the Middle East, Brill, 2009, p. 182.

67 Nafis Alam, Syed Aun R. Rizvi, Islamic Economies: Stability, Markets and Endowments, Springer, 2017, p. 91.

68 Siti Mashitoh Mahamood, Waqf in Malaysia: Legal and Administrative Perspectives, (University of Malaya Press, 2006), p. 43.
}

the colonization period, and the Indonesia's independence period. In the kingdom period, waqf was governed by local customs. In the colonization period, there were various views on the management of waqf. Meanwhile in the independence period, waqf has been governed by various regulations. ${ }^{69}$ However, there remain no problems in the vertical and horizontal relationship among regulations.

During the reform period, when the demand of regional and religious identity gets stronger, the Government forms the law of waqf (Law Number 41 year 2004). Based on socio-historical, juridical and philosophical considerations, wakaf has become one of the living laws for Muslim society in Indonesia. For Muslim society in Indonesia, waqf works in line with the ideals of law, which is rooted in social life, and gets juridical confirmation. Although waqf has fulfilled the criteria of living law, it does not necessarily become an "enforced law". The law enforcement of waqf provisions can be done when the law of waqf has either vertically or horizontally systematic ways within the law of Indonesia, which is supported by clean and prestigious law enforcers and a high legal awareness from law advocates. So, waqf is strongly embedded to the development of Islam and Islamic propagation in Indonesia. There are a lot of religious organizations, mosques, boarding schools, and educational institutions built on waqf land. ${ }^{70}$

Since 2000, waqf has attracted huge attention in Indonesia, from practitioners, academics and government. This condition is seen from the emerging discussion in printed mass media and electronic media. It is essential for waqf to be developed with various goals, such as education, health, the empowerment of people's economy, and many other sectors. Indonesia has made adequate regulation as the basis of waqf management that is in line with the provisions of Islamic law, such as Law Number 41 Year 2004

${ }^{69}$ Amelia Fauzia, Faith and the State: A History of Islamic Philanthropy in Indonesia, Brill, 2013, pp. 29-30.

$7^{70}$ Asmah Haji Omar, Languages in the Malaysian Education System: Monolingual strands in multilingual settings, Routledge, 2015, p. 75. 
on waqf and government ordinance Number 42 Year 2006 on the implementation of Law Number 41 Year 2004..$^{11}$ After the ratification of Law Number 41 Year 2004 on waqf, there are some important progresses in the development of waqf in Indonesia, namely: firstly, the recognition of moving object of waqf, including cash waqf in the form of money that is expected to be a source of potential waqf wealth that can be synergized with the property waqf. Secondly, the establishment of Badan Wakaf Indonesia (BWI) as an independent institution in charge of promoting and developing national endowment. ${ }^{72}$

According to data from the Ministry of Religious Affairs of Indonesia in 2010, the number of waqf land in Indonesia reached 414,848 locations with land area of 2,171,041,349.74 M2.73 Meanwhile, in 2016, the Indonesia Waqf Land Data, can be seen as follows:74

\begin{tabular}{|c|c|c|c|c|}
\hline \multicolumn{5}{|l|}{ INDONESIA WAQF LAND DATA } \\
\hline \begin{tabular}{|l|l} 
No & Province \\
\end{tabular} & Amount & Certified & Not yet Certified & Total Amount (M2) \\
\hline 1 Nanggroe Aceh Darussal am & 24.898 & 13.730 & 11.168 & $767.869 .011,58$ \\
\hline 2 Sumatera Utara & 16.280 & 7.761 & 8.519 & $36.035 .460,00$ \\
\hline 3 Sumatera Barat & 6.643 & 4.420 & 2.223 & $212.212 .380,00$ \\
\hline 4 Sumatera Selatan & 6.394 & 3.521 & 2873 & $380.456 .227,29$ \\
\hline 5 Riau & 8.152 & 2.641 & 5.691 & $1.183 .976 .528,00$ \\
\hline 6 f Jambi & 5.918 & 3.785 & 2133 & $13.516 .703,00$ \\
\hline \begin{tabular}{l|l}
7 Bengkulu \\
\end{tabular} & 2.759 & 1.869 & 890.000 & $7.122 .171,22$ \\
\hline 8 Lampung & 14.591 & 8.372 & 6.219 & $22.990 .814,00$ \\
\hline 9 Bangka Belitung & 1.133 & 779.000 & 354.000 & $3.243 .060,00$ \\
\hline 10 Kepulauan Riau & 1.187 & 326.000 & 861.000 & $1.066 .799,00$ \\
\hline 11 DKI Jakata & 7.422 & 4.623 & 2799 & $3.013 .640,00$ \\
\hline \begin{tabular}{l|l}
12 & D.I. Yogyzkarta \\
\end{tabular} & 8.547 & 8.051 & 496.000 & $2.933 .943,00$ \\
\hline 13 Jawa Bara & 74.860 & 45.873 & 28.987 & $116.662 .017,81$ \\
\hline 14| Jawa Tengah & 103.294 & 82.641 & 20.653 & $163.169 .706,97$ \\
\hline 15. Jawa Timur & 74.429 & 54.193 & 20.236 & $58.239 .272,20$ \\
\hline 16 Banten & 20.089 & 11.049 & 9.040 & $39.322 .270,00$ \\
\hline \begin{tabular}{l|l|l|}
17 Bali \\
\end{tabular} & 1.399 & 1.132 & 267.000 & $13.990 .000,00$ \\
\hline 18 Kal imantan Bara & 4.467 & 2.257 & 2210 & $27.544 .360,00$ \\
\hline 19 Kal imantan Tengah & 2.642 & 1.631 & 1011 & $5.778 .500,00$ \\
\hline \begin{tabular}{l|l|l}
20 & Kal imantan Selatan \\
\end{tabular} & 9.265 & 7.582 & 1683 & $58.239 .272,20$ \\
\hline 21 Kal imantan Timur & 3.423 & 772.000 & 2651 & $13.984 .104,00$ \\
\hline 22 Sulawesi Utara & 887.000 & 420.000 & 467.000 & $1.905 .272,70$ \\
\hline 23 Sulawesi Tenggara & 2.386 & 1.516 & 870.000 & $5.225 .958,00$ \\
\hline 24 Sulawesi Tengah & 3.173 & 2.051 & 1.122 & $165.042 .816,23$ \\
\hline 25 Sulawesi Selatan & 10.440 & 5.486 & 4.954 & $1.029 .030 .278,00$ \\
\hline \begin{tabular}{l|l}
26 & Sulawesi Bară \\
\end{tabular} & 2.448 & 571.000 & 1.877 & $3.251 .700,00$ \\
\hline 27 Papua & 346.000 & 142.000 & 204.000 & $694.466,00$ \\
\hline 28 Papua Barat & 338.000 & 105.000 & 233.000 & $591.117,00$ \\
\hline 29 Nusa Tenggara Timur & 1.272 & 1.047 & 225.000 & $5.311 .787,00$ \\
\hline 30 Nusa Tenggara Bara & 12.105 & 7.031 & 5.074 & $25.816 .325,00$ \\
\hline \begin{tabular}{l|l|}
31 & Maluku \\
\end{tabular} & 1.215 & 449.000 & 766.000 & $5.006 .359,00$ \\
\hline \begin{tabular}{l|l|l|}
32 & Maluku Utara \\
\end{tabular} & 1.489 & 605.000 & 543.000 & $30.223 .191,00$ \\
\hline \begin{tabular}{|l|l|}
33 & Gorontalo \\
\end{tabular} & 1.87 & 729.000 & 1.148 & $1.663 .350,00$ \\
\hline Amount & 435.768 & 287.160 & 148.447 & $4.359 .443 .170,00$ \\
\hline
\end{tabular}

Unfortunately, those waqf assets does not have optimal utilization that leads to the less socio-economic role of waqf. Because the

\footnotetext{
${ }^{71}$ Muhammad Ishom, "The Effectiveness..., p. 110.

${ }_{72}$ Mardani, Aspek Hukum Lembaga Keuangan Syariah Di Indonesia, (Jakarta:,PrenadaMedia,2015), p. 9

73 Imam Wahyudi Indrawan "Menggagas Sekolah Nazir", https://bwi.or.id/index.php/ar/publikasi/artikel/1558-menggagassekolah-nazir.html, accessed June, 27, 2018.

74 https://bwi.or.id/index.php/ar/tentang-wakaf/data-wakaf/ data-wakaf-tanah.html, accessed June, 27, 2018.
}

document pledge of waqf (Akta Ikrar Wakaf [AIW]) not yet owned, it mostly leads to the conflict of wagf land, especially between the waqf inheritant and nazir, or the conflict of waqf management between nazir and community.

By seeing the above data, it is imperative that waqf asset should be maximally managed to develop the socio-economic role of waqf in addition to the socialization of land and money waqf because there are still many waqf lands that don not have land certificate and the document pledge of waqf (Akta Ikrar Wakaf [AIW]) leads to the conflict of waqf land, especially between the waqf inheritant and nazir, or the conflict of waqf management between nazir and community. ${ }^{75}$

Waqf as a legal act has been institutionalized and practiced for a long time in Indonesia. It is allegedly said that waqf institution has existed since the arrival of Islam to the Nusantara and it was then developed in line with the development of Islam in Indonesia. The regulation of legal source, technique, procedure, and practices of waqf in the form of regulation is seen to be new, i.e. since the enactment of Law Number 5 Year 1960 on agrarian affairs.

Later on October 27, 2004 President SBY ratified Law Number 41 Year 2004 on waqf. This law covers all matters concerning waqf which includes the definition of waqf, nazir, Officials Pledge Deed of Endowment (Pejabat Pembuat Akta Ikrar Wakaf [PPAIW]), etc. The initiall traditional development of waqf is expected to grow more productive and it covers not only land as waqf property but also movable objects such as money, precious metals, vehicles, etc. The fatwa of Indonesian Ulama Council (Majelis Ulama Indonesia [MUI) allowed the money waqf on May 11, 2002.

\section{Conclusion}

Republic of Indonesia Act Number 41 of 2004 on waqf with its advantages and disadvantages should be addressed with full optimism. This act was born based on the hope that waqf

75 Savran Billahi \& Idris Thaha, Bangkitnya Kelas Menengah Santri Modernisasi Pesantren di Indonesia, (Prenada Media, 2018), p. 137. 
implementation, which has been known by the Muslim community since old time, should be performed in organized and accountable manner. In addition, the object of waqf that formerly was focused on immovable objects, with the presence of this Act has been broader to movable property, especially money waqf. In general, it can be said that some of the contents of this Act refers to Government Regulation (GR) Number 28 of 1977 regarding the Rights of Ownership waqf. The addition of the content of the $G R$ is due to the Act is broaden the object of waqf is not limited to land. The other addition is about the limitation of waqf duration.

\section{References}

Achsien, Iggi H. and Dien L. Purnamasari, "Islamic Crowd-funding as The Next Financial Innovation in Islamic Finance: Potential and Anticipated Regulation in Indonesia", EJIF - European Journal of Islamic Finance, No 5, June, 2016.

Afhan, Muhammad Abu al-, "al-Waqf 'alâ alMasjid fî al-Maghribwa al-Andalūs", in Studies in Islamic Economics, Jeddah: King Abd al-Aziz University, International Center for Reserach in Islamic Economics, 1985

Ahmad, Ahmad Atif, Islamic Law: Cases, Authorities and Worldview, Bloomsbury Publishing, 2017.

Alawiah, Siti and Ismail, Yusof "Strategic planning and accountability of waqf management in Malaysia" $4^{\text {th }}$ International conference on Inclusive Islamic Financial Sector Development, 17th-18th Nov. 2015, International Islamic University Islamabad, Unpublished.

Alpay, Savaş and Mohamed Aslam Haneef (eds.), Integration of Waqf and Islamic Microfinance for Poverty Reduction: Case Studies of Malaysia, Indonesia and Bangladesh, IIUMSESRIC, 2015.

Armagan, Servet, "Lamhah'an Hâlat al-Awqâf fî Turki”, in Hasan'AbdAllâh al-Amîn, Idârawa TathmîrMumtalaka al-Awqâf, Jeddah: Islamic Research and Training Institute (IRTI) of the Islamic Development Bank, 1989
Asiyah, Nur \& Abdul Ghofur, "Kontribusi Metode Mashlahah Mursalah Imam Malik terhadap pengembangan Hukum EkonomiSyari'ah Kontemporer", Al-Ahkam, 27 (1), 2017.

Asyhar, Thobib Al-, "Substansi Undang-Undang Nomor 41 Tahun 2004 tentang Wakaf", Paper in Workshop of PemberdayaanWakaf di Jawa Barat", 2006.

Atabik, Ahmad "Strategi Pendayagunaan dan Pengelolaan Wakaf Tunai di Indonesia", ZISWAF, Vol. 1, Number 2, December, 2014.

Awar, Abdulla Mohammed Al, "Awakening the Awqaf: Islamic endowments represent a sleeping giant within the Islamic finance sector and the broader Islamic economy", 2015, http://gulfnews.com/business/sectors/ banking/awakening-the-awqaf-1.1595663, accessed 17 August 2017.

Babaca, Mehmet, Economics of Philanthropic Institutions, Regulation, and Governance in Turkey", Journal of Economic and Social Research, Vol. 13.(2), 2011.

Baihaqî, Abû Bakr Ahmad Ibn al-Husayn Ibn 'Alî al-, al-Sunan al-Kubrâ, J. VI, Al-Hamîd: Mathba'ah Dâ'irah al-Ma'ârif al-Uthmâniyya. $1352 \mathrm{H}$.

Bearman, Peri, The Ashgate Research Companion to Islamic Law, Routledge, 2016.

Beverley, Eric Lewis, "Property, Authority and Personal Law: Waqf in Colonial South Asia" South Asia Research,Vol. 31, 2011

Billahi, Savran \& Idris Thaha, Bangkitnya Kelas Menengah Santri Modernisasi Pesantren di Indonesia, Prenada Media, 2018

Budiman, Mochammad Arif, "The Significance of Waqf for Economic Development" Equilibrium, Volume 2, Number 1, June 2014.

Dahdah, Edouard Al-, Cristina CorduneanuHuci, Gael Raballand, Ernest Sergenti, and MyriamAbabsa., Rules on Paper, Rules in Practice Enforcing Laws and Policies in the Middle East and North Africa, Directions in development. Washington, D.C.: World Bank Group, 2016. http://documents.worldbank. org/curated/en/491731469074817610/Ruleson-paper-rules-in-practice-enforcing-laws- 
and-policies-in-the-Middle-East-and-NorthAfrica, accessed 17 August 2017.

Diharto, "Revitalization through Innovation WAQF Property Traditional Development" The International Journal of Business \& Management, Vol 4 Issue 9 September, 2016.

Effendi, Deden, Penegakan Hukum Wakaf di Indonesia", Ph.D Dissertation of UIN (Universitas Islam Negeri) Sunan Gunung Djati, Bandung, 2011.

Elasrag, Hussein, Towards a new role of the institution of waqf, Online at https://mpra. ub.unimuenchen.de/80513/ MPRA Paper Number 80513, posted 1 August 2017 05:31 UTC.

Farid, Diana, "The Waqf of Money as a Community Economic Empowerment Efforts", International Journal of Nusantara Islam, Vol. 4, Number 2, 2016, http://dx.doi. org/10.15575/ijni.v4i2.1068.

Fatoohi, Louay, Abrogation in the Qur'an and Islamic Law, Routledge, 2012.

Fauzia, Amelia, Faith and the State: A History of Islamic Philanthropy in Indonesia, Brill, 2013.

Hasan, Zunaidah Ab, Azhana Othman, Khalilah Ibrahim, Mohd Ab Malek Md Shah, Abd. Halim Mohd Noor, "Management of Waqf Assets in Malaysia" International Journal of Nusantara Islam, Vol. 3, Number 1, 2015. http://dx.doi.org/10.15575/ijni.v3i1.412;

Hasanah, Uswatun, "The Role of Indonesian Waqf Board in Promoting and Developing Waqf in Indonesia", Indonesian Management \& Accounting Research, Vol. 13, Number 2, July 2014.

Hatina, Meir, Guardians of Faith in Modern Times: 'ulama' in the Middle East, Brill, 2009.

http://dx.doi.org/10.15575/ijni.v3i1.314

https://bwi.or.id/index.php/ar/tentang-wakaf/ data-wakaf/data-wakaf-tanah.html, accessed June, 27, 2018.

Ibrahim, Amir \& Masron., "Cash Waqf: An Innovative Instrument for Economic Development", International Review of Social Sciences and Humanities, Vol. 6, Number 1, 2013.
Ihsan, Hidayatul, Shahul Hameed $\mathrm{Hj}$. Mohamed Ibrahim, "WAQF accounting and management in Indonesian WAQF institutions: The cases of two WAQF foundations" Humanomics, Vol. 27, Issue: 4, 2011, https://doi. org/10.1108/08288661111181305.

Indrawan, Imam Wahyudi, "Menggagas Sekolah Nazir". https://bwi.or.id/index.php/ar/ publikasi/artikel/1558-menggagas-sekolahnazir.html, accessed June, 27, 2018.

Ishom, Muhammad, Siraj Sait, "The Relevance of Islamic Land Law for Policy and Project Design" Conference on Challenges for Land Policy and Administration, Washington DC., the World Bank. 2008.

Ishom, Muhammad, "The Effectiveness of Law Number 41 Year 2004 About Regulation of Productive Waqf" Jurnal Bimas Islam, Vol.7. Number IV, 2014.

Ishom, Muhammad, Hosen, Nadirsyah, "Religion and Indonesian constitution: A recent debate" Journal of Southeast Asian Studies, Vol. 36, Issue 03, October 2005, http://dx.doi. org/10.1017/So022463405000238.

Ishom, Muhammad, Suryani and Yunallsra, "Wakaf Produktif (Cash Waqf) dalam Perspektif Hukum Islam dan Maqâshid AlSharî́ah" Walisongo: Jurnal Penelitian Sosial Keagamaan, Vol. 24 Number 1, May 2016.

Joseph, Sabrina, "Waqf in Historical Perspective: Online fatâwâ and Contemporary Discourses by Muslim Scholars", Journal of Muslim Minority Affairs, Vol. 34, Number 4, 2014, http://dx.doi.org/10.1080/13602004.2014.9 65974.

Kayadibi, Saim, Istihsan: The Doctrine of Juristic Preference in Islamic Law, The Other Press, 2010.

Khadduri, Majid \& Herbert J. Liebesny, Origin and Development of Islamic Law, The Lawbook Exchange, Ltd 2008.

Kusha, Hamid R, "The Sacred Law of Islam: A Case Study of Women's Treatment in the Islamic Republic of Iran's Criminal Justice System", Routledge, 2017.

Mahamood, Siti Mashitoh, Waqf in Malaysia: Legal 
and Administrative Perspectives, University of Malaya Press, 2006.

Mahata, Jaaffara \& Rasool, "Potential of Micro-Waqf as an Inclusive Strategy for Development of a Nation", International Accounting and Business Conference 2015, $I A B C$ 2015, Procedia Economics and Finance, Vol.31, 2015.

Malik, Adeel "Was the Middle East's economic descent a legal or political failure? Debating the Islamic Law Matters Thesis", CSAE Working Paper, WPS/2012-08, 2012, Centre for the Study of African Economies Department of Economics. University of Oxford.

Mardani, Aspek Hukum Lembaga Keuangan Syariah Di Indonesia, Prenada Media, 2015.

Mariam, Siti Malinumbay S. Salasal, The Concept of Land Ownership: Islamic Perspective, Buletin Geoinformasi, Penerbitan Akademik Fakulti Kejuruteraan \& Sains Geoinformasi, Jld. 2 Number 2, ms. 285-304, December 1998.

Mesutldriz, "Waqf Property and Its Administration in the Ottoman Empire: a Case of Manastir with Special Reference to 18th Century Judicial Records. Hikmet: IlmiArastrima Dergisi, Journal of Scientific Research, 2005.

Mikail, Ahmad, “Perspective of Siyasah Shar'iah in Application of Cash Waqf Transfer for Islamic Financial Industry: Indonesian Study Case", Proceeding of the 5th Islamic Economics System Conference (iECONS 2013), "Sustainable Development Through the Islamic Economics System", Organized By Faculty Economics And Muamalat, Universiti Sains Islam Malaysia, Berjaya Times Square Hotel, Kuala Lumpur, 4-5th September 2013.

Mohamad, Nor Asiah, Sharifah Zubaidah Syed Abdul Kader \& Zuraidah Ali, "Waqf Lands and Challenges from the Legal Perspectives in Malaysia", IIUM-Toyo Joint Symposium 2012. Sustainable Built Environment: lesson learned from Malaysia and Japan.

Mohamad, Noraini, Zahanum Zulkifli" The Role of Higher Institutions in Creating Awareness on Challenges of MUIP in Communicating its Waqf Possession" International Journal of Nusantara Islam, Vol. 3, Number 1, 2015,, http://dx.doi.org/10.15575/ijni.v3i1.413;

Mubarok, Jaih, Wakaf Produktif, Bandung, Simbiosa Rekatama Media, 2008.

Muflichah, Siti, “ Implementation and Protection of Legal Law on Cash Waqf Toward Tabung Wakaf Indonesia of Dompet Dhuafa Jakarta" Jurnal Dinamika Hukum, Vol. 17 Number 2, May 2017.

Mutalib, Hasyeilla Abd \& Selamah Maamor, "Utilization of Waqf Property: Analyzing an Institutional Mutawalli Challenges in Management Practices", International Journal of Economics and Financial Issues, Vol. 6 Number S7, 2016.

Nafis Alam, Syed Aun R. Rizvi, Islamic Economies: Stability, Markets and Endowments, Springer, 2017.

Nafis, Cholil, "Rethinking” Fiqih Wakaf. https:// bwi.or.id/index.php/in/publikasi/artikel/751rethinking-fiqih-wakaf.html, accessed June, 27, 2018.

Omar, Asmah Haji, Languages in the Malaysian Education System: Monolingual strands in multilingual settings, Routledge, 2015.

Pianciola, Niccolo and Paolo Sartori, "Waqf in Turkestan: the colonial legacy and the fate of an Islamic institution in early Soviet Central Asia, 1917-1924", Central Asian Survey, Vol. 26, Number 4, December 2007.

Purwanto, Yedi, HariUtomo, Rasyida Noor, "Nazir Al-Waqf in Imam Syafi'i's View and its Implementation in Indonesia", International Journal of Nusantara Islam, Vol. 4, Number 2, 2016, http://dx.doi.org/10.15575/ijni.v4i1.1202.

Qamariyanti, Yulia, "The Contextual of Waqf in Philosophy of Islamic Law Based on the Qur'an and Hadith" LamLaj, Volume 1 Issue 1, March 2016.

Rahman, Farhana Mohamad Suhaimi and AsmakAb, "The role of share waqf in the socio-economic development of the Muslim community The Malaysian experience", Humanomics, Vol. 30, Number 3, 2014. http:// dx.doi.org/10.1108/H-12-2012-0025.

Raimi, Lukman, "Waqf and Zakah as Social 
Safetynets for Poverty Reduction in Nigeria", WIEF-UiTM Occasional Papers, 2nd Edition, 2015.

Raimi, Lukman, Ashok Patel and Ismail Adelopo, "Corporate social responsibility, Waqf system and Zakat system as faith-based model for poverty reduction", World Journal of Entrepreneurship, Management and Sustainable Development, Vol. 10 Number 3, 2014, http://dx.doi.org/10.1108/WJEMSD09-2013-0052.

Ramadhan, Mustafe Muhammad, "Daur alAuqâf fî Da'm al-Azhar", in Proceeding of the Symposium of Awqaf Institutions in the Arab and Islamic World, Institute of the Arab Research and Studies, Bagdad, 1983.

Rani, Mohd Afandi Bin Mat, "Fatwa on Waqf: Specialized Analysis in Hand Over of Waqf Lands by State Authority", International Journal of Nusantara Islam, Vol. 3, Number 1, 2015, http://dx.doi.org/10.15575/ijni.v3i1.411.

Rofai, Yuli, Umar Burhan, Multifiah Multifiah. The Role of Productive Waqf for Public Welfare (Study Case of Nadzir Foundation in University of Islam Malang). International Journal of Social and Local Economic Governance, Vol 2, No 2,2016.

Rothstein, Bo \& Rasmus Broms, "Governing religion: the long-term effects of sacred Financing" Journal of Institutional Economics/ FirstView Article/September, 2013,. http:// dx.doi.org/10.1017/S1744137413000271

Rozalinda, "The Economic Empowerment of the Ummah on the Basis of Productive Waqf in West Sumatra, Indonesia", International Journal of Nusantara Islam, Vol .03, No .01, 2015.

Sait, Siraj, "Unexplored dimension: Islamic land system in Afghanistan, Indonesia, Iraq, and Somalia". in Jon Unruh, Rhodri Williams, Land and Post-Conflict Peacebuilding, Routledge, 2013.

Salleh, Muhammad Syukri" Rethinking Wealth Management: An Islamic Preliminary View" International Journal of Business and Social Science, Vol. 3, Number 13, July 2012.
Shaikh, Salman Ahmed, Abdul Ghafar Ismail, and Muhammad Hakimi Mohd Shafiai, "Application of waqf for social and development finance", ISRA International Journal of Islamic Finance, Vol. 9 Number 1 , 2017. http://dx.doi.org/10.1108/IJIF-07-2017002.

Siraj Sait and Hilary Lim, Land, Law and Islam: Property and Human Rights in the Muslim World, Zed Books, London \& New York, 2006.

Sudirman, "Regulasi Wakaf di Indonesia Pasca Kemerdekaan Ditinjau dari Statute Approach" de Jure, Jurnal Syariah dan Hukum, Vol. 6 Number 2, December 2014.

Sukasih, KamaruzamanYusoff and Mansoureh Ebrahimi" Humanism Values in the 1945 Constitution of Republic of Indonesia", The Social Sciences, Vol. 11, Number 5, 2016.

Suleiman, Haitam, "The Islamic Trust waqf: a Stagnant or Reviving Legal Institution?" Electronic Journal of Islamic and Middle Eastern Law (EJIMEL), Vol. 4, 2016.

Tawfiq, Muhammad Amin, "The Awqaf in Modern Egypt" The Islamic Quarterly, vol. XLII, Number 4, 1998.

Thoarlim, Abdulsoma, Md. Asadur Rahman \& Anas Yanya, "Cash Waqf in Bangladesh and the Need for Innovative Approach towards Awqâf: Lessons from Selected Countries", International Journal of Academic Research in Business and Social Sciences, Vol. 7, Number 4, 2017. http://dx.doi.org/10.6007/IJARBSS/ v7-i4/2795.

Trakic, Adnan, "A Legal and Administrative Analysis of Inalienable Muslim Endowments (Awqâf) in Bosnia and Herzegovina" Islam and Civilisational Renewal, Vol. 3, Number 2, January 2012.

Vandendael, Anouk, Bas Hagoort, Jelle van Balen, \&JoppeTer Meer, Stimulating Civil Society from the Perspective of an INGO: an Explorative Study of Indonesia, (Rotterdam School of Management: Erasmus University, 2013.

Widyawati, "The Politics of Islamic Philanthropy in the post-Soeharto Indonesia: A Study of 
the2004 Waqf Act" Advances in Natural and Applied Sciences,Vol. 6, Number 8, 2012.

Zin, Mohamad Zaid Mohd, Ahamad Asmadi Sakat, Nurul Khairiah Khalid Nurfahiratul Azlina Ahmad, Mohd Roslan Mohd Nor, Azri Bhari, Saurdi Ishak and Mohd Arip Kasmo,
"Products of Islamic Finance: A Shariah Compliance Advancement" Australian Journal of Basic and Applied Sciences, Vol. 5, Number 12, 2011. 